\title{
ВОЛОДИМИР СЕРАФИМОВИЧ ВАХРУШЕВ (ВІД ПУБЛІКАТОРА)
}

\author{
Ігор Козлик
}

Доктор філологічних наук, професор, завідувач кафедри,

Кафедра світової літератури і порівняльного літературознавства, Прикарпатський національний університет імені Василя Стефаника (УКРАЇНА),

76018, м. Івано-Франківськ, вул. Шевченка, 57, e-mail: ihor.kozlyk@pnu.edu.ua

\section{PЕФЕРАТ}

У статті, яка $є$ післямовою до надрукованої вище в перекладі на українську мову методологічної статті російського літературознавця, доктора філологічних наук, професора В. С. Вахрушева (1932-2011) «Про метамову гуманітарної наукової думки», подано біографічні відомості про російського гуманітарія, дана стисла характеристика його методологічної та загальнокультурної позиції, охарактеризовано його ставлення до своєї і чужої культури та його погляди на завдання філологічної освіти, вказано на причини здійсненої публікації його неопублікованої раніше праці у перекладі на українську мову.

Ключові слова: В. С. Вахрушев, гуманістаристика, методологія літературознавства, метамова гуманітарної науки.

\section{VOLODYMYR SERAFYMOVYCH VAKHRUSHEV (FROM THE EDITOR)}

\author{
Ihor Kozlyk \\ Professor Doctor Habilitatus of Philology, Head of Department, \\ Department of World Literature and Comparative Literary Criticism, \\ Vasyl Stefanyk Precarpathian National University (UKRAINE), \\ 76018, Ivano-Frankivsk, 57, Shevchenko str., \\ e-mail: ihor.kozlyk@pnu.edu.ua
}

\begin{abstract}
The article, which is an afterword to the methodological article by the Russian literary critic, Doctor of Philological Studies, Professor V.S. Vakhrushev (1932-2011) «About the metalanguage of humanitarian scientific thought» published in translation into Ukrainian. It contains biographical information about the Russian humanitarian, a brief description of his methodological and general cultural position, his attitude to his own and other cultures and his views on the tasks of philological education. The reasons for the publication of his previously unpublished work translated into Ukrainian are also defined in the article. humanities.

Key words: V.S.Vakhrushev, humanities, methodology of literary criticism, metalanguage of

Володимир Серафимович Ва́хрушев (9.09.1932, Стрілки, Кіровська обл., РФ - 27.01.2011, Балашов, Саратовська обл., РФ) - російський літературознавець, доктор філологічних наук, професор, працював на кафедрі літератури (тепер кафедра російської мови і літератури) і (за сумісництвом) на кафедрі англійської мови (тепер кафедра іноземних мов) Балашовського інституту Саратовського державного університету імені М. Г. Чернишевського (тепер Балашовський інститут Саратовського національного дослідного
\end{abstract}


державного університету імені М. Г. Чернишевського), де читав лекції 3 античної і зарубіжної, зокрема української літератури, та 3 віршознавства. Заняття із зарубіжної літератури та країнознавства проводив i англійською мовою. Вільно володів також французькою і німецькою мовами, а польську, українську та словацьку мови знав тією мірою, яка дозволяла працювати з оригінальними текстами на цих мовах.

Закінчив Кіровський державний педагогічний інститут імені В. І. Леніна (тепер В'ятський державний гуманітарний університет В'ятського державного університету) за спеціальністю «учитель англійської мови», аспірантуру при кафедрі історії зарубіжної літератури Московського державного університету імені М. В. Ломоносова, де 1965 року захистив кандидатську дисертацію «Історичні романи Джека Ліндсея» (науковий керівник - доктор філологічних наук, професор кафедри історії зарубіжної літератури МДУ імені М. В. Ломоносова В. В. Івашева ${ }^{1}$ [див.: 8]), а 1985 - докторську дисертацію «Творчість Теккерея» (офіційні опоненти: доктор філологічних наук, професор, завідувач кафедри зарубіжної літератури Московського обласного педагогічного інституту iм. Н. К. Крупської 3. Т. Гражданська ${ }^{2}$, доктор філологічних наук, завідувач кафедри історії літератури Московського поліграфічного інституту О. Т. Парфенов ${ }^{3}$, доктор філологічних наук, професор кафедри зарубіжної літератури Київського державного університету ім. Т. Г. Шевченка К. О. Шахова ${ }^{4}$; провідна організація - Красноярський державний педагогічний інститут [див.: 11]).

\footnotetext{
1 Іва́шев а Валентина Василівна (1908-1991) - російський літературознавець i критик, один із фундаторів російської англістики. Випускниця Ленінградського університету. Захистивши докторську дисертацію з творчості Ч. Діккенса, у подальшому займалася здебільшого англійською літературою ХХ ст., причому, що було рідкістю в радянські часи, часто виїжджала до Великобританії, де особисто зустрічалася 3 багатьма письменниками. Саме вона запропонувала В. С. Вахрушеву тему кандидатської дисертації, про що він згадує так: «Взагалі я мріяв працювати над темою „Творчість Джека Лондона”, але мій науковий керівник Валентина Василівна Івашева нав'язала мені „іншого Джека” - не американця, а англійця. Ї̈і вибір пояснити просто: правнучка декабриста Івашева, засланого до Сибіру, вона сама сама була вислана з Ленінграда на сім років в казахський аул, а її перший чоловік офіцер Червоної Армії, був розстріляний як „ворог народу”. Тому Валентина Василівна боялася будь-яких відступів від партійної лініїі в науці. Джек Лондон здавався їй „ідеологічно слизьким” - так мені було сказано. А ось Джек Ліндсей (не лише імена збігаються, а й прізвища подібні, обидва озвучені на „л-н-д”) був зовсім інша справа - комуніст, друг СРСР, борець за мир, до того ж пише „прогресивні романи”. Чи було щось краще? Так що залишалося взятися за „зовсім іншого Джека”» [9, c. 4].
}

${ }^{2}$ Гражда́нська Зоя Тихонівна (1916-1991) - російський літературознавець. Закінчила Московський обласний педагогічний інститут ім. Н. К. Крупської, захистила докторську дисертацію з творчості Б. Шоу, у подальшому займалася англійською літературою XVIII-XX ст.

3 Парфенов Олександр Тихонович (1930-1996) - російський літературознавець. Випускник філологічного факультету Московського державного університету ім. М. В. Ломоносова, де його однокурсниками і друзями були такі відомі у майбутньому діячі російської культури, як літературний критик Станіслав Лесневський (1930-2014) та літературознавець-теоретик, доктор філологічних наук, професор Валентин Халізєв (1930-2016). Фахівець 3 літератури і культури доби Відродження, займався також проблемами взаємодії і взаємовпливу російської та зарубіжної літератур.

${ }^{4}$ Ша́хова Кіра Олександрівна (1926-2003) - український літературознавець. Закінчила Київський державний університет ім. Т. Г. Шевченка, була першим в Україні доктором наук з історії угорської літератури. У сферу іiї наукових інтересів входили проблеми західноєвропейської та американської літератур XIX-XX ст. Приділяла 

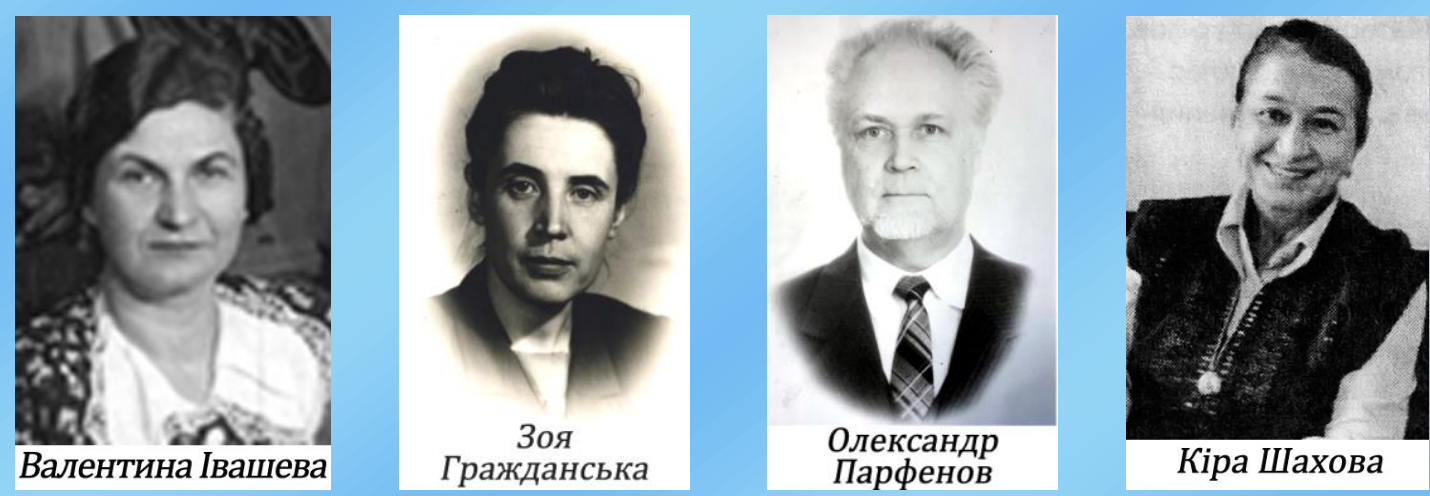

В. С. Вахрушев досліджував творчість Едуарда Булвер-Літтона, Гомера, Артура Кларка, Джозефа Конрада, Плавта, А. Конан-Дойла, Бернарда Шоу (статті про них увійшли до видання: [6]). Він також $є$ автором низки літературно-краєзнавчих студій. Праці вченого побачили світ у фахових виданнях Росії, Польщі, Німеччини та Білорусі.

Найціннішими досягненнями $\quad$ В. С. Вахрушева, зазначено на сайті кафедри іноземних мов Балашовського інституту СДУ, є концепція гри як основи функціонування художнього тексту, концепція жанру як універсальної ідейно-пізнавальної структури і концепція входження «малої історії» в історичний контекст світової культури [див.: 4]. Завдяки книзі «Великий, як сонце, Балашов» (рос. «Большой, как солнце, Балашов...», 2007), місто Балашов «перетворилося з адміністративної одиниці районного масштабу на місто-текст, що виникає на перетині і переплетенні часів, свідчень, міфів. <..> Назви нових дисциплін - гуманітарна географія та локальна історія, мабуть, найбільш точно пояснюють жанр Вахрушева» [5].

«Універсальний учений, - зазначає Б. Ф. Сгоров, - Володимир Серафимович Вахрушев <...> поряд 3 вивченням художніх текстів студіював праці 3 найрізноманітніших галузей гуманітарних знань: літературознавство, мовознавство, мистецтвознавство, філософія, історія, культурологія, релігієзнавство, соціологія, краєзнавство, педагогіка. I, будучи творчою особистістю, майже у всіх перелічених сферах залишив і свої дослідження, кількість яких сягає за 300» [13, с. 25].

Позицію В. С. Вахрушева - справжнього вченого-гуманітарія - у ставленні до рідної культури у кореляції 3 інонаціональним культурним спадком найкраще характеризує вступна стаття до його книги «Уроки світової літератури в школі». Тоді в середині 1990-х років російський філолог писав: «В останні роки в багатьох школах Росії долається, нарешті, панівний донедавна лінгвістичний моноцентризм, який був однією 3 головних перешкод до оволодіння світовою культурою. <..> Моноцентризм шкідливий і при вивченні рідної літератури. Бажано використовувати будь-яку можливість для порівняння і зіставлення російських письменників із зарубіжними - чи йдеться 
про близьке чи про далеке зарубіжжя. Широкий погляд на світ, що формується при знайомстві 3 літературами різних народів, дасть молодим людям упевненість у собі, особливо коли вони навчаться критично засвоювати духовні цінності минулого і теперішнього. <...>

У роки радянської влади у нас боялися відкрито обговорювати важкі питання міжнаціональних відносин. Проте ці проблеми підспудно загострювалися, пристрасті розпалювалися, що і спричинило неочікуваний для багатьох розпад СРСР, страшні конфлікти, війни як між різними (часто спорідненими) народами , так і всередині окремих націй. Однією з причин <..> такої катастрофи буда політика властей, які тривалий час здійснювали „русифікацію” радянської культури. <...>

Цей лінгвістичний монополізм відображався і в практиці російської школи. <..> I тепер чимало школярів і деякі вчителі не замислюються над тим, що Сервантес, якого вони вивчають у школі, писав іспанською, Гете німецькою. Для таких учнів і викладачів чуже уявлення про перекладача. <..> Варто замислитися і над таким цікавим явищем, як білінгвізм, двомовність. Росіянам, які володіють лише рідною мовою, непогано було би повчитися у вірмен, якутів, чукчів та інших народів СНД, які - незалежно від їхнього рівня культури - спілкуються зазвичай двома мовами, своєю і російською. Білінгвізм властивий i декотрим відомим письменникам. Пушкін писав вірші французькою... Російською і своєю рідною, українською, писав Тарас Шевченко. Дещо французькою творив Тургенєв... Ще більш цікавий в аспекті білінгвізму Володимир Набоков, котрий спочатку створив англійською мовою роман „Лоліта” і став популярним американським автором, а потім переклав або, точніше, перетворив свій англо-американський роман російською. Це дає чудовий матеріал для розуміння того, як можна наочно уявити взірець світової літератури. Цікавим є і досвід Чингіза Айтматова <...> Спочатку він сам перекладав свої

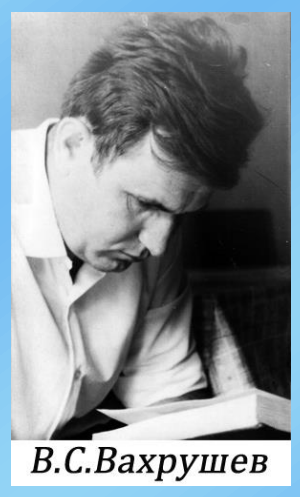
киргизькі тексти російською, потім став творити російською, і вже опісля перекладав свої російські твори рідною киргизькою мовою. На Заході ж його широко знають за перекладами 3 російської на англійську, німецьку, французьку й ін. <..>

Що таке світова література? Насамперед це безперервний процес взаємообміну інформацією, у якому відбувається кодування і декодування різних мов і систем спілкування. Культура в цьому сенсі моделює природу, в якої теж безліч мов» $[12$, с. $3,4,5]$.

Певну роль у житті В. С. Вахрушева відіграла й Україна, з якою він був пов'язаний i біографічно, і професійно. У 1956-1957 роках Володимир Серафимович служив у лавах радянській армії на Волині, в ракетному дивізіоні в Ковелі (районний центр Волинської обл.) та Любомлі (Ковельского р-ну Волинської обл.). Про своє перебування у війську та атмосферу тих років він оповідає у мемуарній книзі «Тиха моя батьківщина», де читаємо: «В армії я здавав екзамени екстерном на звання офіцера запасу. Зібрали із Закарпатського округу чоловік десять солдат з вищою освітою в місто Рівне. Чергова дурість - 
ніхто в армії не виховував нас (але ж буди політінформації регулярно) на місцевих прикладах, прив'язаних до місцевості. Жодного слова ми не чули про ковельських партизанів, про бої наших частин в Передкарпатті <...>

Під час екзаменів познайомилися один 3 одним, та прізвищ колег не запам’ятав... Якось латиш з Риги, симпатичний блондин, влаштував мені допит, чи я знаю німецьку. Певний рівень знання я продемонстрував, хоча рижанину не сподобався мій російський акцент. Та він милостиво дав мені свою ризьку адресу - мовляв, заходь, якщо будеш у нашому місті. А потім він і ще один русин, міцний хлопець з Ужгородської області, поговорили зі мною по душах: „А хочеш, ми скажемо тобі, чому ми не любимо росіян?” Я відповідаю: „Ну, кажіть”. Вони: „А тому, що ви нас гнобите, не даєте нашим націям свободи”. Я: „Це я вас гноблю? Та якщо йдеться про свободу, то і в нас, росіян, іiі мало візьміть хоча б наші колгоспи". Словом, сперечалися без запеклості, посміхаючись, але кожен залишився зі своєю думкою.
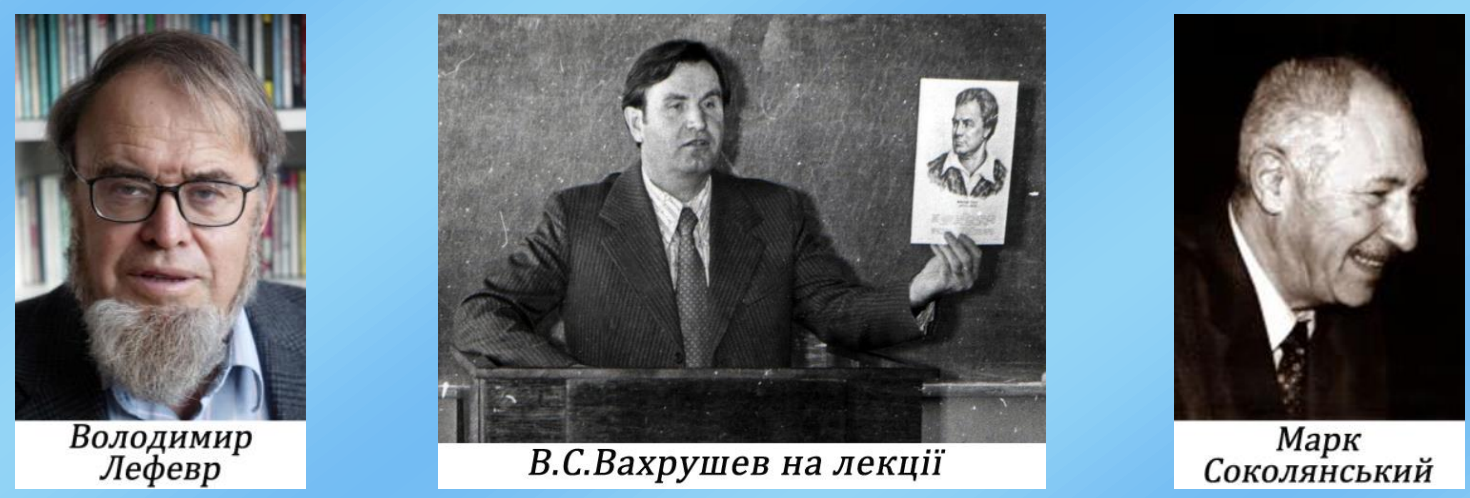

Незабаром ми роз’іхалися і більше не бачилися. Гадаю, тепер мої колеги по офіцерському званню, рижанин і русин із Закарпаття, отримали бажану свободу від росіян, але від цього не стали до нас ставитися краще.

Про військо ще скажу, що там, у Любомлі, у нашому ракетному дивізіоні, я познайомився 3 Володимиром Лефевром, майбутнім професором Каліфорнійського університету у місті Берклі, творцем теорії рефлексивного мислення <...>» [10, с. 91]

Крім читання лекцій про творчість окремих українських письменників та занять 3 перекладу українських поетів на російську мову, 3 Україною B. С. Вахрушева пов’язує справжня багаторічна дружба 3 Марком

\footnotetext{
5 Лефе́вр Володимир Олександрович (англ. Lefebvre, 1936, Ленінград, РСФСР - 2020, США) російський і американський психолог і математик, кандидат психологічних наук, професор одного 3 10-ти кампусів (університетських містечок) Каліфорнійського університету, розташованого в Ірвайні (в Берклі знаходиться головний кампус Каліфорнійського університету). Створив теорію рефлексивних ігор i термодинамічної моделі рефлексії, концепції рефлексивна система, рефлексивне керування грою, був першим, хто вивів вивчення рефлексії з-під впливу ідеологічного контролю. 1968 закінчив механіко-математичний факультет МДУ ім. М. В. Ломоносова (Москва), 1971 захистив кандидатську дисертацію з психології, у 19691974 очолював наукову групу в науково-дослідному Центральному економіко-математичному ін-ті АН СРСР, 1974 емігрував до США. Крім наукових праць, до творчого спадку вченого входять публіцистичні роботи, присвячені поточним проблемам суспільного життя, перспективам сучасної науки, конфліктам між наукою і вірою, структурі моральної свідомості, віртуальній реальності і майбутньому Росії, джерелам демографічної кризи, помилкам миротворництва й ін.
} 
Георгійовичем Соколянським (нар. 1939, Ленінград, у 1956-1993 жив і працював в Одесі, з 1993 живе в Любеку, Німеччина) - літературознавцем і театрознавцем, учнем О. А. Анікста, доктором філологічних наук, професором, випускником (1960) філологічного факультету (спеціальність «російська мова $\mathrm{i}$ література») Одеського державного університету ім. І. І. Мечнікова. У $1962-$ 1993 роках він працював на кафедрі зарубіжної літератури цього вишу. М. Г. Соколянський - автор понад 300 праць, опублікованих в Україні, Росії, Великобританії, Польщі, ФРН, Нідерландах, США, Ізраїлі, Латвії, Канаді, Італії, Угорщині та ін. країнах. В. С. Вахрушева та М. Г. Соколянського, крім іншого, поєднувала сфера наукових інтересів, куди входили проблеми історії західноєвропейських (зокрема англійської) літератур, компаративістики, питання теорії літератури, шекспірознавства ${ }^{6}$.

У 2006 році у В. С. Вахрушева виникли зв'язки з Івано-Франківськом. Саме тоді мене, ще кандидата філологічних наук, доцента кафедри світової літератури ПНУ імені Василя Стефаника познайомив 3 В. С. Вахрушевим професор Б. Ф. Сгоров. Тож останні 5 років життя Володимира Серафимовича ми мали змогу принагідно спілкуватися в епістолярний спосіб ${ }^{7}$, пам'ятаючи один про одного.

Основні пращуі В. С. Вахрушева: «Джек Линдсей. Жизнь и творчество: (из истории русско-английских культурных связей)» (Саратов: Изд-во Саратовского ун-та, 2007. 101 с.), «Поэтика английского романа XVI-XVIII веков» (Балашов: Николаев, 2008. 237 с.), «Уильям Теккерей. Жизнь и творчество» (Балашов: Изд-во «Николаев», 2009. 100 с.), «Жанровая поэтика русского и английского романа XVII-XIX веков в контексте мировой литературы» (Балашов: Балашовский ин-т Саратовского ун-та: ИП О. А. Николаев, 2010. 104 с.), «Образ. Текст. Игра: Очерки по теории литературы: учеб. пособие для учителей литературы, преподавателей вузов, студентов-филологов» (Балашов: Николаев, 2002. 127 с.), «Уроки мировой литературы в школе: кн. для учителя: Из опыта работы» (Москва: Просвещение, 1993. 158 с. 1995. 226 с.), «,Большой, как солнце, Балашов...”: (очерки по истории и культуре среднего Прихопёрья)» (2-е изд., испр. и доп. Балашов: Николаев, 2007. 261 с.), воспоминания «Тихая моя родина» (Балашов: Изд-во «Николаев», 2008. 130 с.).

Лim.: Вахрушев В. С. Библиография. Тематический указатель. Балашов, 2007. 44 с. Литературное произведение и культурный контекст (сборник статей в честь 70-летия профессора В. С. Вахрушева). Becbl: альманах гуманитарных кафедр Балашовского института (филиала) Саратовского гос. ун-та им. Н. Г. Чернышевского: персональный выпуск. Балашов, 2002. № 18. 136 с. Подхваченное слово....: сб. науч. статей: посвящается памяти профессора Владимира Серафимовича Вахрушева / подгот. Ж. Н. Масловой. Тамбов: Изд-во Тамбовского гос. ун-та (ТГУ), 2014. 212 с. (Див.. також: В музее открылась выставка «Профессорское наследие», посвященная Вахрушеву. BezFormata [Электронный pecypc] 2019. 11 января. URL: https://balashov.bezformata.com/listnews/nasledie-posvyashennayavahrushev u/38471345/ ).

Стаття В. С. Вахрушева 1993 року «Про метамову гуманітарної наукової думки» друкується вперше. На думку Б. Ф. Сгорова, вона має фундаментальний характер і $€$ «вершиною самостійних праць ученого» [13, с. 32]. В iї основі -

\footnotetext{
6 Детальніше про М. Г. Соколянського див.: [7; $1 ; 3]$.

7 Декілька листів В. С. Вахрушева до мене заплановано до друку у виданні, яке готується на його батьківщині 3 нагоди 90-річчя від дня народження балашовського вченого.
} 
текст доповіді, яку автор готував на одну 3 конференцій 1990-х років, організованих Саратовським Міжрегіональним центром з вивчення художнього тексту. Звернення В. С. Вахрушева до зазначеної у назві статті проблематики було ініційоване інтересом до філологічних статей про дослідницьку метамову в ㄲï стосунку до мови художнього тексту, особливо до статті Б. Л. Борухова «Проблема точності і міф про математику», присвяченої 70-річчю Ю. М. Лотмана, автор якої розглядає творчу еволюцію тартуського вченого [див.: 2]. Екземпляр альманаху «АРТ», що зберігся в сім'ї В. С. Вахрушева, «весь списаний його примітками, зокрема їх багато i на берегах статті Б. Л. Борухова». На останній 194-й сторінці статті міститься велике резюме В. С. Вахрушева: «Ми самі визнаємо (розум $з$ розуму - Кант, мистецтво таємниця), та однаково прагнемо це раціоналізувати! Хоча все - в метафору (i це визнання - Лотман). Це наш внесок в ноосферу? не піти у надмірне раціо? Позаяк це шкодить (варвар), потрібно віддатися ГРІ Буття (за Ніцше), але вводити іiі в межі класики (цільно), а не фрагментів, щоб не втрапити у „Футурологічний конгрес” Ст. Лема» $[13, \text { с. } 33]^{8}$.

Підтримуючи загальний зміст статті еволюції Лотмана від спроб створити „математично” строгу мову до розширення попереднього опертя на традиційну мову», В. С. Вахрушев «усе ж заперечує застереження Борухова про необхідність „точноі” наукової мови» $[13$, c. 33].

В. С. Вахрушев підтримує присутнє у Б. Л. Борухова «розрізнення двох „точностей” - істинність і наукова строгість, але йде далі: стверджує метафоричність „точності”, і тому прагнення до точності - це спроба визначити неосяжне (художні тексти) невизначеним, тобто створюючи ніби нову апорію Зенона» $[13$, с. 33]. Застосовуючи свій філософський i лінгвістичний універсалізм, вчений прагне насамперед уточнити поняття точності: «,Точність” - конгломерат трьох значень: фізичного (від дієслова „ткнути”), геометричного i, особливо, - філософського. Точка, за О.Ф. Лосєвим, $\epsilon$ „принципом будь-якої єдинороздільної цілісності... Вона є і виражальною потугою будь-якого цільного буття i саме́ це цільне буття". Так В. С. <Вахрушев> за допомогою філософа переводить точку з „математики” в ігрову осцилюючу ${ }^{9}$ метафоричність.

Те ж саме В. С. <Вахрушев> чинить і з „істиною”, спираючись у цьому на Гайдеггера. Не-істина, тобто „прихованість сущого в цілому”, виявляється давнішою від об'яви сущого; людство, тільки блукаючи і помиляючись, виходить на шлях істини. А складний шлях від не-істини Буття до розкриття істини виявляється дублікатом шляху мистецтва у своїй хиткій кореляції протилежностей, а отже, отримує ігровий характер. На цій підставі В. С. <Вахрушев> оригінально подає крупномасштабне поняття гри, значно розширюючи свої попередні формулювання: „,..це вічний процес

\footnotetext{
8 Для зручності читацького сприйняття авторські скорочення слів у цитованому уривку замінено повним написанням.

${ }^{9}$ Осцилююч ча - тут: мінлива, пульсуюча.
} 
взаємоперетворення Буття i Небуття, Єдиного і Множини, Сущого i $\mathrm{He}$ Сущого, Свободи і Необхідності, а також процес взаємоперетворень самого цього процесу в результат і результату в процес". У світлі такої універсальності В. С. $<$ Вахрушев> далі буде розглядати й ігрові властивості науки.

Таким чином, - підсумовує Б. Ф. Сгоров, - усе виявляється включеним у гру і навіть саме по собі стає грою (зокрема і все Буття!). В. С. $<$ Вахрушев $>$ спирається на Геракліта: „Вік - дитя, що грається, кості кидає”. I тим паче грою стає мистецтво (тут В. С. <Вахрушев> спирається на Канта і Шіллера), що пропонує множинність істин (скажімо, в різних художніх тлумаченнях складних історичних подій і постатей). Тому мистецтво, сповнене метафор, дає „метафоричність” істини (тут йде покликання на Ніцше: істина - „пані метафор", „армія метафор”), i через те точність у мистецтвознавстві метафорична. Упродовж всієї статті про метамову В. С. $<$ Вахрушев $>$ ніби пояснює і виправдовує підсилення метафоричності у пізніх працях Лотмана» $[13$, c. 33-34].

Електронну копію оригінального російськомовного машинописного тексту статті В. С. Вахрушева «О метаязыке гуманитарной научной мысли» для публікації українською мовою люб'язно надав редакції «Султанівських читань» професор Борис Федорович Сгоров (Санкт-Петербург, РФ) ${ }^{10}$. Переклад тексту українською мовою, підготовка до друку, примітки і коментарі до нього належать мені. У перекладі збережено основні мовно-стилістичні особливості автора.

Стаття В. С. Вахрушева «Про метамову гуманітарної наукової думки» друкується на вшанування пам'яті вченого і з метою обговорення порушених в ній актуальних епістемологічних і методологічних питань розвитку сучасної гуманітарної науки, зокрема літературознавства, у 2-й половині XX - перших десятиліттях XXI століття ${ }^{11}$.

\section{ЛІТЕРАТУРА}

1. Бирштейн А. Кого потеряла Одесса. Мигдаль Times. 2008. № 99. URL: https://www.migdal.org.ua/times/99/17528/.

2. Борухов Б. Л. Проблема точности и миф о математике. АРТ Альманах исследований по искусству : сб. науч. трудов / ред. Б. Л. Борухов. Саратов : Сар. гос. пед. ин-т им. К. А. Федина, 1993. Вып. 1. С. 177-194.

3. Черноиваненко Е. М. Марк Георгиевич Соколянский. 2011. 30 августа. URL: http://philolog.onu.edu.ua/uk/memory/sokolyansky/.

4. Кафедра иностранных языков филологического факультета БИ СГУ. URL: https://www.sgu.ru/structure/bisgu/filolbal/kafinjasbal/history.

10 Див. про вченого в розділі «In memoria» цього випуску «Султанівських читань».

11 Вважаю своїм обов'язком висловити щиру подяку за сприяння у пошуку джерел необхідної інформації та консультативну допомогу у процесі підготовки рукопису статті В. С. Вахрушева до друку та написанні цієї післямови: дочці В. С. Вахрушева, доктору філологічних наук, доценту Людмилі Комуцци (Татару) (Балашов, РФ), доктору філологічних наук, професору Борису Єгорову (СПб., РФ), доктору філологічних наук, професору Марії Михайловій (Москва, РФ), доктору філологічних наук, професору Ігорю Лосієвському (Харків, Україна), доктору філологічних наук, старшому науковому співробітнику Галині Александровій (Київ, Україна), кандидату філологічних наук, доценту Олександру Чуранову (Балашов, РФ). 
5. Лебедушкина О. Владимир Вахрушев : «Текст города рождается на пересечении взглядов на одни и те же звёзды...» <Интервью>. Первое сентября: газета для учителя. 2007. № 17. 8 сентября. Четвёртая тетрадь. Идеи. Судьбы. Времена. URL: https://ps.1sept.ru/article.php?ID=200701740.

6. Зарубежные писатели : биобиблиографический словарь : в 2 ч. / под ред. Н. П. Михальской. Москва : Просвещение ; Учебная литература, 1997. (Новое изд., перераб. и доп. - Москва : Дрофа, 2003).

7. Панченко В. Марк Соколянський : «Для мене Одеса - не просто населений пункт» $<$ Ексклюзивне інтерв'ю>. ЛітАкиент. 2008. 29 лютого. URL: http://litakcent.com/2008/02/29/dlja-mene-odesa-ne-prosto-naselenyi-punkt/.

8. Вахрушев В. С. Исторические романы Джека Линдсея : автореф. дис. ... канд. филол. наук. Москва, 1964. 17 с.

9. Вахрушев В. С. Джек Линдсей. Жизнь и творчество: (из истории русско-английских культурных связей). Саратов : Изд-во Саратовского ун-та, 2007. 101 с.

10. Вахрушев В. С. Тихая моя родина. Балашов : Изд-во «Николаев», 2008. 130 с.

11. Вахрушев В. С. Творчество Теккерея: автореф. дис. д-ра филол. наук : 10.01.05. Москва, 1985. 32 c.

12. Вахрушев В. С. Уроки мировой литературы в школе : 5-11 кл. : кн. для учителя. Москва : Просвещение : ВЛАДОС, 1995. 228 с.

13. Егоров Б. Ф. Игровые аспекты культуры : концепции Ю. М. Лотмана и В. С. Вахрушева. Семиосфера нарратологии : диалог языков и культур : междунар. сб. науч. ст. / под общ. ред. Л. В. Татару, Х. А. Гарсия Ланды. Балашов : Николаев, 2013. С. 25-36.

\section{REFERENCES}

1. Birshtein, A. (2008), "Whom Odessa lost" ["Kogo poteryala Odessa"], Migdal. Times, No. 99, available at: https://www.migdal.org.ua/times/99/17528/. (in Russian).

2. Borukhov, B.L. (1993), "The problem of accuracy and the myth of mathematics" ["Problema tochnosti i mif o matematike"], ART Almanakh issledovaniy po iskusstvu: sb. nauch. trudov, Saratov, Issue 1, pp. 177-194. (in Russian).

3. Chernoivanenko, Ye.M. (2011), "Mark Georgievich Sokolansky" ["Mark Georgievich Sokolyanskiy"], August 30, available at: http://philolog.onu.edu.ua/uk/memory/sokolyansky/. (in Russian).

4. Department of foreign languages of philology faculty BI SSU, available at: https://www.sgu.ru/structure/bisgu/filolbal/kafinjasbal/history. (in Russian).

5. Lebedushkina, O. (2007), "Vladimir Vakhrushev: "The text of the city is born at the intersection of views on the same stars..." ["Vladimir Vakhrushev: "Tekst goroda rojdaetsya na peresechenii vzglyadov na odni i te je zvezdy..."'], Pervoe sentyabrya: gazeta dlya uchitelya, No. 17 September 8, available at: https://ps.1sept.ru/article.php?ID=200701740. (in Russian).

6. Mikhalskaya, N.P. (Ed.). (1997), Foreign writers: biobibliographic dictionary: in 2 parts [Zarubejnye pisateli: biobibliograficheskiy slovar v $2 \mathrm{ch}$.], Prosveschenie, Uchebnaya literatura, Moscow. (New edition, revised and enlarged - 2003, Drofa, Moscow) (in Russian).

7. Panchenko, V. (2008), "Mark Sokolansky: 'For me, Odessa is not just a settlement"” ["Mark Sokolansky: ' Dlia mene Odesa - ne prosto naselenyi punkt], LitAktsent, February 29, available at: http://litakcent.com/2008/02/29/dlja-mene-odesa-ne-prosto-naselenyi-punkt/. (in Ukrainian).

8. Vakhrushev, V.S. (1964), Jack Lindsay's historical novels: Author's thesis [Istoricheskie romany Djeka Lindseya: avtoref. dis. ... kand. filol. nauk], Moscow, 17 p. (in Russian).

9. Vakhrushev, V.S. (2007), Jack Lindsay. Life and Work: (from the History of Russian-English Cultural Relations) [Djek Lindsey. Zhizn i tvorchestvo: (iz istorii russko-angliyskikh kulturnykh svyazey)], Izd-vo Saratovskogo un-ta, Saratov, 101 p. (in Russian).

10. Vakhrushev, V.S. (2008), My quiet homeland [Tikhaya moya rodina], Izd-vo "Nikolayev", 130 p. (in Russian).

11. Vakhrushev, V.S. (1985), Thackeray's creativity: Author's thesis [Tvorchestvo Tekkereya: 
avtoref. dis. d-ra filol. nauk], Moscow, 32 p. (in Russian).

12. Vakhrushev, V.S. (1995), World literature lessons at school: 5-11 grades: book for teacher [Uroki mirovoy literatury $v$ shkole: 5-11 kl: kn. dlya uchitelya], Prosveschenie, VLADOS, Moscow, 228 p. (in Russian).

13. Yegorov, B.F. (2013), "Game aspects of culture: the concepts of Yu.M. Lotman and V.S. Vakhrushev", Semiosphere of Narratology: Dialogue of Languages and Cultures: Intern. book scientific. articles, in Tataru, L.V. and Garsiya Landa, Kh.A. (Eds.) ["Igrovyie aspekty kultury: kontseptsii YU.M. Lotmana i V.S. Vakhrusheva", Semiosfera narratologii: dialog yazykov i kultur: mezhdunar. sb. nauch. st., pod obsch. red. L.V. Tataru, H.A. Garsiya Landy] , Nikolaev, Balashov, pp. 25-36. (in Russian).

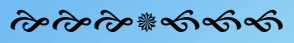

